\title{
Problematika Ketenagakerjaan di Kota Batam Menurut Undang-Undang Nomor 13 Tahun 2003 tentang Ketenagakerjaan
}

\author{
Febri Handayani*, Lysa Angrayni \\ Fakultas Syariah dan Hukum UIN Sultan Syarif Kasim \\ Jalan Raya Pekanbaru-Bangkinang, Kota Pekanbaru 28293, Indonesia
}

\begin{abstract}
Abstrak
Tujuan penelitian ini menjelaskan problematika hubungan ketenagakerjaan di Kota Batam menurut Undang-Undang Nomor 13 Tahun 2003 tentang Ketenagakerjaan. Jenis penelitian ini penelitian hukum normatif-empiris (applied law research), yaitu melihat hukum dalam kenyataan. Hasil penelitian ini dapat dijelaskan bahwa problematika ketenagakerjaan di Kota Batam terkait PKWT dan upah. Faktor-faktor penyebab problematika ketenagakerjaan di Kota Batam, yaitu faktor yuridis, berupa kekeliruan penafsiran undang-undang, kelemahan sistem register, tidak diaturnya sanksi terhadap pelanggaran PKWT dan lemahnya sistem pengawasan ketenagakerjaan. Kebijakan pemerintah daerah mengatasi problematika ketenagakerjaan hanyalah melakukan pengawasan yang berkaitan dengan perlindungan norma kerja. Kesimpulan penelitian ini bahwa secara tekstual hukum ketenagakerjaan telah cukup memberikan pengakuan dan jaminan hukum terhadap hak-hak buruh. Namun, penegakan hukumnya masih lemah sehingga belum mampu mewujudkan perlindungan hak-hak buruh. Ada beberapa faktor penyebab problematika ketenagakerjaan di Kota Batam. Tidak banyak yang dapat dilakukan oleh Pemerintah Daerah Kota Batam dalam menangani permasalahan ketenagakerjaan. Upaya dilakukan, seperti pencatatan PKWT dan koreksi terhadap PKWT yang belum memenuhi peraturan, melakukan koreksi atas peraturan perusahaan yang memerlukan pengesahan, melakukan proses mediasi terhadap permasalahan tenaga kerja, dan memberikan saran-saran untuk perbaikan.
\end{abstract}

Kata Kunci: Problem, Ketenagakerjaan, Batam

\begin{abstract}
The purpose of this study explains the problems of labor relations in Batam City according to Law Number 13 Year 2003 on Labor. This type of research is normativeempirical law research (applied law research), which sees the law in reality. The results of this study can be explained that the problems of employment in the city of Batam associated PKWT and wages. Factors causing employment problems in Batam City, namely juridical factors, in the form of mistaken interpretation of the law, the weakness of the system registers, not regulated sanctions against violations of PKWT and weak labor inspection system. The policy of the local government to overcome the problems of labor is only to conduct supervision relating to the protection of work norms. The conclusion of this research is that textually labor law has enough to give legal recognition
\end{abstract}

"Penulis Korespondensi

E-mail: febrihandayanimh@gmail.com 
and guarantee to labor rights. However, its law enforcement is still weak so it has not been able to realize the protection of labor rights. There are several factors causing labor problems in Batam. Not much can be done by Batam City Local Government in handling labor issues. Efforts such as recording of PKWT and corrections to PKWT that have not complied with regulations, correcting company regulations requiring validation, mediating labor issues, and providing suggestions for improvement.

\section{Keywords: Problem, Employment, Batam}

\section{Pendahuluan}

Tenaga kerja merupakan pelaku pembangunan dan pelaku ekonomi, baik secara individu maupun secara kelompok. Sumberdaya tenaga kerja di Indonesia jumlahnya melimpah. Indikasi ini bisa dilihat dari masih tingginya jumlah pengangguran di Indonesia karena minimnya lapangan kerja.

Untuk itu, pembangunan dan pertumbuhan ekonomi harus ditingkatkan agar memberikan kesempatan yang luas bagi pencari kerja. Selain membuka lapangan kerja, hal yang harus diperhatikan selanjutnya memberikan perlindungan hukum, membina, dan mengarahkan tenaga kerja. Perlindungan hukum terhadap tenaga kerja bertujuan untuk menghapus sistem perbudakan dan menjaga agar tenaga kerja lebih dimanusiakan. Untuk menjalankan perlindungan terhadap tenaga kerja itu diperlukan perencanaan dan pelaksanaan yang komprehensif, terpadu, dan berkeseimbangan. Hal ini mengingat bahwa kedudukan tenaga kerja/buruh selalu dianggap lebih rendah dari majikan, sehingga diperlukan adanya campur tangan pemerintah. Padahal, secara yuridis kedudukan pengusaha dan pekerja sama dan sederajat. Namun, secara sosiologis dalam kondisi tertentu buruh berada pada posisi yang lemah. ${ }^{1}$
Untuk memberikan perlindungan hukum tenaga kerja, Pemerintah harus membuat regulasi yang melegitimasi perlindungan hukum tersebut. Perlindungan hak pekerja mendapat jaminan dalam Undang-Undang Dasar Negara Kesatuan Republik Indonesia Tahun 1945 pada Pasal 27 Ayat (2), Pasal 28 D Ayat (1), Pasal 28D Ayat (2). Ketentuan tersebut menegaskanbahwa hak bekerja memperoleh tempat yang penting dan dilindungi oleh UndangUndang Dasar. Ketentuan lebih lanjut dijabarkan dalam Undang-Undang Nomor 13 Tahun 2003 tentang Ketenagakerjaan pada Pasal 5 dan 6. Pasal 5 mengatur bahwa "setiap tenaga kerja memiliki kesempatan yang sama tanpa diskriminasi untuk memperoleh pekerjaan". Selanjutnya, Pasal 6 ditegaskan bahwa "setiap pekerja/buruh berhak memperoleh perlakuan yang sama tanpa diskriminasi dari pengusaha". Dengan demikian, pada hakikatnya tenaga kerja mempunyai kedudukan baik dari segi yuridis maupun sosial ekonomis.

Meskipun demikian, ketenagakerjaan di Indonesia tidak bebas dari problem hukum dan sosial. Menurut Zainal Asikin problematika terkait ketenagakerjaan berpangkal pada ketidakpuasan tenaga kerja pada masalah: ${ }^{2}$

1. Pengupahan.

2. Jaminan sosial.

${ }^{1}$ Fenny Natalia Khoe, Hak Pekerja yang Sudah Bekerja Namun Belum Menandatangani Perjanjian Kerja Atas Upah Ditinjau Atas Upah Berdasarkan Undang-Undang Nomor 13 Tahun 2003 tentang Ketenagakerjaan, Jurnal Ilmiah Mahasiswa Universitas Surabaya, Volume 2, Nomor 1, 2013, hlm.3.

${ }^{2}$ R. Joni Bambang S, Hukum Ketenagakerjaan, (Bandung: Pustaka Setia, 2013), hlm. 289. 
3. Perilakupenugasanyangkadangkadang dirasakan kurang sesuai dengan kepribadian.

4. Daya kerja dan kemampuan kerja yang dirasakan kurang dengan pekerjaan yang harus diemban.

5. Adanya masalah pribadi.

Berangkat dari problem ketenagakerjaan maka perlindungan terhadap tenaga kerja menjadi hal yang harus diperhatikan. Perlindungan terhadap tenaga kerja diawali dari adanya hubungan kerja antara pemberi kerja dan tenaga kerja. Hubungan kerja merupakan hubungan hukum yang dilakukan oleh minimal dua subjek hukum, yaitu pengusaha dan pekerja/buruh mengenai suatu pekerjaan. ${ }^{3}$ Menurut Asri Wijayanti, hubungan kerja adalah hubungan hukum antara buruh dan pemberi kerja yang memiliki unsur adanya pekerjaan, upah dan perintah. ${ }^{4}$ Hubungan kerja terjadi setelah adanya perjanjian kerja antara buruh dengan majikan atau pemberi kerja.

Gambaran mengenai problematika tenaga kerja dapat diambil contoh pada sentra industri di Pulau Batam. Pulau Batam merupakan zona industri yang strategis karena berbatasan langsung dengan Singapura dan Malaysia serta terletak di Selat Melaka. Jumlah tenaga kerja di Pulau/Kota Batam cukup besar, seimbang dengan banyaknya perusahaan yang beroperasi di sana.

Berkaitan dengan itu, Kota Industri menjadi citra yang melekat pada Kota Batam. Kota Batam menawarkan lapangan kerja yang besar bagi para tenaga kerja. Lebih dari 300.000 tenaga kerja ada di Kota Batam tersebar di 5.700 perusahaan yang bergerak di bidang pertanian (46), pertambangan (31), industri (1996), bidang listrik, gas, air (17), bangunan (821), perdagangan, dan hotel (1324), pengangkutan dan komunikasi (189), keuangan (500), serta jasa-jasa (776). ${ }^{5}$ Namun, dari banyaknya jumlah tenaga kerja di Kota Batam, tidak semuanya merasakan kehidupan yang lebih baik karena masih banyak terjadi kesenjangan terkait perlindungan terhadap tenaga kerja. Salah satu bentuk kesenjangan, seperti pola hubungan kerja yang sistemnya menjadi otoritas pihak perusahaan. Hal ini biasanya terjadi pada perusahaan-perusahaan kecil atau perusahaan pada level subcon.

Kondisi riil kehidupan tenaga kerja di Kota Batam menuntut disesuaikannya upah dengan standar pasar. Berdasarkan Keputusan Gubernur Kepulauan Riau Nomor 1737 Tahun 2015 tentang Upah Minimum Kota Batam Tahun 2016 ditetapkan bahwa upah minimum kota (UMK) Kota Batam adalah sebesar Rp 2.994.111,00 (dua juta sembilan ratus sembilan puluh empat ribu seratus sebelas rupiah) perbulan. Dari sisi UMK, sudah mendapat perhatian yang baik dari pemerintah karena kebijakan upah telah melindungi hak tenaga kerja.

Namun disisi lain, masalah perlindungan hak tetap muncul walaupun tidak memperlihatkan gejolak yang berarti. Probematika ketenagakerjaan yang sering terjadi berkaitan dilanggarnya aturan perjanjian kerja waktu tertentu (PKWT). Menggunakan tenaga kerja dengan sistem kontrak atau dikenal juga dengan

3I Nyoman Wahyu Triana dan I Made Udiana, Kesepakatan Pemutusan Hubungan Kerja (PHK) Melalui Perjanjian Bersama Ditinjau Dari Aspek Hukum Ketenagakerjaan, Jurnal Kertha Semaya, Volume 04, Nomor 04, Juli 2016, hlm. 3.

${ }^{4}$ Asri Wijayanti, Menggugat Konsep Hubungan Kerja, (Bandung: CV Lubuk Agung, 2011), hIm. 55. 
nama perjanjian kerja waktu tertentu (selanjutnya disebut PKWT), secara normatif tidak dilarang. Bahkan PKWT diatur jelas dalam Pasal 56 sampai dengan Pasal 59 UndangUndang Nomor 13 Tahun 2003 tentang Ketenagakerjaan. Selain itu, PKWT juga diatur dalam Keputusan Menteri Tenaga Kerja dan Transmigrasi Nomor Kep.100/men/VI/2004 tentang Ketentuan Pelaksanaan Perjanjian Kerja Waktu Tertentu. Sesuai aturan tersebut PKWT hanya bisa dilakukan untuk pekerjaan:

1. Pekerjaan yang sekali selesai atau sementara sifatnya.

2. Pekerjaan yang diperkirakan penyelesaiannya paling lama tiga tahun.

3. Pekerjaan yang bersifat musiman.

4. Pekerjaan yang berhubungan dengan produk baru, kegiatan baru, produk tambahan yang masih dalam percobaan atau penjajakan.

Dengan demikian, PKWT tidak dapat diadakan untuk pekerjaan yang bersifat tetap. Namun, PKWT dapat diperpanjang atau diperbarui selama satu tahun dan jika menyimpang dari ketentuan tersebut maka demi hukum PKWT menjadi perjanjian kerja waktu tidak tertentu (PKWTT). ${ }^{6}$

Problematika ketenagakerjaan lainnya berkaitan dengan perusahaan pada level subcon untuk level yang sama pada maincon upah bisa saja berbeda. Sistem subcon dalam hubungan ketenagakerjaan bisa saja merugikan hak-hak tenaga kerja. Perjanjian kerja (dalam hal ini sering disebut kontrak), biasanya sangat singkat, yaitu antara 3 (tiga) sampai 6 (enam) bulan. Ketika kontrak masih berlangsung atau menjelang masa kontrak habis, perusahaan merevisi kontrak menjadi 1 (satu) tahun, tetapi hitungan 3 (tiga) atau 6 (enam) bulan sebelumnya (pada kontrak awal) tidak dihitung sebagai kontrak pertama, tetapi jadi satu kesatuan dengan kontrak yang direvisi. Revisi ini bahkan ada yang dibuat berkali-kali. ${ }^{7}$

Problematika ketenagakerjaan berikutnya juga sering terjadi, yaitu pelanggaran terhadap norma kerja. Tenaga kerja merasakan hakhaknya kurang terpenuhi meskipun secara normatif dilindungi oleh hukum, seperti norma cuti hamil, menjalankan ibadah dan sebagainya. Problematika ketenagakerjaan di Kota Batam Menurut Undang-Undang Nomor 13 Tahun 2003 tentang Ketenagakerjaan belum pernah ditulis sebelumnya. Meskipun ada penelitian-penelitian terdahulu tidak membahas isu yang sama.

Penelitian Shinta Wahyu Hati dkk hanya meneliti tentang motivasi kerja terhadap kondisi sosial ekonomi tenaga kerja wanita di sektor industri. ${ }^{8}$ Shinta Wahyu Hati sendiri pernah meneliti tentang analisis keselamatan dan kesehatan kerja (K3) pada pembelajaran di laboratorium Program Studi Teknik Mesin Politeknik Negeri Batam. ${ }^{9}$ Adi Neka Fatyandri dan Evi Silvana Muchsinati pernah meneliti tentang pengaruh dan peran manajer SDM terhadap

${ }^{5}$ Badan Pusat Statistik Kota Batam, berdasarkan data yang dihimpun dari Dinas Tenaga Kerja Kota Batam (data s.d. Oktober 2014), http://www. batamkota.bps.go.id/linkTabelStatis/view/id/20, diakses tanggal 25 Maret 2016.

${ }^{6}$ Lihat Pasal 59 Undang-Undang Nomor 13 Tahun 2003 tentang Ketenagakerjaan.

${ }^{7}$ Ahmadi Sultan, Habis Kontrak, Buruh Dibuang: Ironi Karyawan Kontrak di Batam, http:// arsip.batampos.co.id/10-08-2015/, diakses tanggal 25 Maret 2016.

${ }^{8}$ Shinta Wahyu Hati dkk, Motivasi Kerja Terhadap Kondisi Sosial Ekonomi Tenaga Kerja Wanita di Sektor Industri, Proceeding Applied Business and Engineering Conference (ABEC) 2014, hlm. 27.

${ }^{9}$ Shinta Wahyu Hati, Analisis Keselamatan dan Kesehatan Kerja (K3) pada Pembelajaran di Laboratorium Program Studi Teknik Mesin Politeknik Negeri Batam, Prosiding SNE Pembangunan Manusia Melalui Pendidikan Dalam Menghadapi ASEAN Economic Community 2015, hlm. 1. 
keharmonisan hubungan industrial di Kota Batam. ${ }^{10}$ Dwi Afni Maileni pernah meneliti tentang tanggung jawab Badan Nasional Penempatan dan Perlindungan Tenaga Kerja Indonesia Kota Batam dalam peningkatan mutu dan kualitas calon tenaga kerja Indonesia tinjauan Undang-Undang Nomor 39 Tahun 2004 tentang Penempatan dan Perlindungan Tenaga Kerja Indonesia di Luar Negeri. ${ }^{11}$ Asep Ahmad Saetuloh, pernah meneliti tentang kebijakan ketenagakerjaan pada sektor industri di Kota Batam. ${ }^{12}$ Irene Svinarky pernah meneliti tentang analisis kinerja karyawan dari dampak perjanjian kerja waktu tertentu (PKWT) terhadap kepuasan perusahaan di PT Osi Electronics di Kota Batam Periode Tahun 2013. ${ }^{13}$

Menelaah hasil dan kesimpulan dari penelitian-penelitian terdahulu tersebut tidak membahas isu yang sama dengan penelitian ini. Dengan demikian, penelitian ini merupakan sesuatu yang baru, atau berbeda dengan penelitian terdahulu (novelty). Berdasarkan hal itu, maka penelitian ini penting dilaksanakan karena dapat menambah khasanah bagi ilmu pengetahuan.

Adapun permasalahan yang dibahas dalam penelitian ini, yaitu Pertama, apa problematika ketenagakerjaan di Kota Batam menurut Undang-Undang Nomor 13 Tahun 2003 tentang Ketenagakerjaan? Kedua, apa faktor-faktor yang menyebabkan problematika ketenagakerjaan di Kota Batam? Ketiga, bagaimana kebijakan Pemerintah Daerah Kota Batam mengatasi problematika ketenagakerjaan?

Hasil yang diharapkan dari penelitian ini: Pertama, menjelaskan problematika ketenagakerjaan di Kota Batam menurut Undang-Undang Nomor 13 Tahun 2003 tentang Ketenagakerjaan. Kedua, menjelaskan faktor-faktor problematika ketenagakerjaan di Kota Batam. Ketiga, menjelaskan kebijakan Pemerintah Daerah Kota Batam mengatasi problematika ketenagakerjaan. Selain itu, penelitian ini diharapkan dapat dijadikan pengembangan ilmu pengetahuan khususnya hukum ketenagakerjaan.

\section{Metode Penelitian}

\section{Jenis penelitian}

Jenis penelitian ini penelitian hukum normatif-empiris (applied law research), yaitu melihat hukum dalam kenyataan. Penelitian hukum normatif-empiris ini bermula dari kajian hukum positif tertulis. Kajian hukum positif tertulis dapat disebut sebagai penelitian hukum doktrinal, ${ }^{14}$ yaitu penelitian yang berupa usaha penemuan hukum in concreto yang layak diterapkan untuk menyelesaikan suatu perkara hukum tertentu.

${ }^{10}$ Adi Neka Fatyandri dan Evi Silvana Muchsinati, Pengaruh dan Peran Manajer SDM Terhadap Keharmonisan Hubungan Industrial di Kota Batam, Jurnal Manajemen, Volume 14, Nomor 1, November 2014, hlm. 1.

${ }^{11}$ Dwi Afni Maileni, Tanggung Jawab Badan Nasional Penempatan dan Perlindungan Tenaga Kerja Indonesia Kota Batam Dalam Peningkatan Mutu dan Kualitas Calon Tenaga Kerja Indonesia Tinjauan UndangUndang Nomor 39 Tahun 2004 tentang Penempatan dan Perlindungan Tenaga Kerja Indonesia di Luar Negeri, Jurnal Petita, Volume 2, Nomor 2, Desember 2015, hlm. 159.

${ }^{12}$ Asep Ahmad Saetuloh, Kebijakan Ketenagakerjaan pada Sektor Industri di Kota Batam, JurnalKajian, Volume 16, Nomor 1, Maret 2011, hlm. 190.

${ }^{13}$ Irene Svinarky, Analisis Kinerja Karyawan Dari Dampak Perjanjian Kerja Waktu Tertentu (PKWT) Terhadap Kepuasan Perusahaan di PT Osi Electronics di Kota Batam Periode Tahun 2013, Jurnal Cahaya Keadilan, Volume 3, Nomor 1, 2015, hlm. 19.

${ }^{14}$ Suratman dan Philips Dillah, Metode Penelitian Hukum, Cet. Ke-2, (Bandung: Alfabeta, 2014), hlm. 45. 


\section{Lokasi penelitian}

Sesuai dengan judul dan fokus kajian yang diteliti maka penelitian ini berlokasi di Kota Batam dengan alasan banyak menyerap tenaga kerja dan menghadapi berbagai problematika terkait hubungan kerja dan hak-hak tenaga kerja.

\section{Populasi dan sampel}

Populasi adalah keseluruhan atau himpunan obyek dengan ciri yang sama. Populasi dan teknik sampling dalam penelitian ini tergambar pada tabel berikut:

\section{Jenis Populasi dan Teknik Sampling}

\begin{tabular}{cll}
\hline No. & \multicolumn{1}{c}{ Populasi } & \multicolumn{1}{c}{ Teknik Sampling } \\
\hline 1. & Tenaga Kerja & Random Sampling \\
2. & $\begin{array}{l}\text { Pihak-pihak terkait pada Dinas } \\
\text { Tenaga Kerja }\end{array}$ & Purpossive Sampling \\
\hline
\end{tabular}

Berdasarkan tabel diatas dapat dijelaskan bahwa penetapan sampel disesuaikan dengan keadaan populasi pada saat penelitian. Untuk penetapan sampel yang berasal dari tenaga kerja digunakan metode random sampling dengan memperkirakan jumlah populasi sekitar 300.000 tenaga kerja diambil sampel sebanyak 50 (lima puluh) orang, yaitu sekitar 0,017\%. Penetapan sampel yang berasal dari Dinas Tenaga Kerja Kota Batam berdasarkan penunjukan dari instansi terkait berjumlah 2 orang.

\section{Teknik pengumpulan data}

Sudah selazimnya dalam penelitian normatif-empiris (applied law research) data yang dipergunakan berupa data primer dan sekunder. Data primer diperoleh berdasarkan pengumpulan data di lapangan dilakukan dengan cara observasi dan wawancara sampel terpilih. Dalam hal ini, sampel terkait adalah tenaga kerja, pihak perusahaan dan Dinas Tenaga Kerja. Data sekunder diperoleh dengan studi kepustakaan terhadap literatur yang berkaitan dengan permasalahan yang diteliti.

\section{Analisisi data}

Analisis data yang digunakan dalam penelitian ini adalah analisis kualitatif. Dengan analisis tersebut akhirnya diperoleh suatu penarikan kesimpulan dengan metode induktif.

\section{Pembahasan}

Problematika Ketenagakerjaan di Kota Batam Menurut Undang-Undang Nomor 13 Tahun 2003 tentang Ketenagakerjaan

Batam sebagai salah satu ikon daerah industri di Indonesia sampai saat ini memiliki sekitar 21 (dua puluh satu ) kawasan industri (dapat dilihat pada tabel 1), didiami oleh sejumlah perusahaan dalam berbagai bidang usaha (dapat dilihat pada tabel 2). Tentunya tidak akan terlepas dari berbagai problematika ketenagakerjaan yang kompleks, bahkan mengarah pada pelanggaran hak-hak tenaga kerja. 
Tabel 1

Kawasan Industri di Kota Batam

\begin{tabular}{|c|c|c|}
\hline No. & Nama Kawasan Industri & Pemilik \\
\hline 1. & Batamindo Industrial Park & $\begin{array}{l}\text { Gallant Venture Pte Ltd - PT Verizon } \\
\text { Indonesia }\end{array}$ \\
\hline 2. & Cammo Industrial Park & PT Aman Sejati Propertindo \\
\hline 3. & $\begin{array}{l}\text { Citra Buana Centre Park } \\
\text { Phase II }\end{array}$ & PT Citra Buana Batam Industri \\
\hline 4. & Malindo Cipta Perkasa & - \\
\hline 5. & $\begin{array}{l}\text { Citra Buana Centre Park } \\
\text { Phase III }\end{array}$ & PT Citra Buana Prakarsa \\
\hline 6. & $\begin{array}{l}\text { Citra Buana Industrial Park } \\
\text { Phase I }\end{array}$ & PT Citra Buana Prakarsa \\
\hline 7. & Executive Industrial Park & $\begin{array}{l}\text { PT Bumiabadi Tegarsakti/Anggota dari } \\
\text { ADRGroup Jkt }\end{array}$ \\
\hline 8. & Hijrah Industrial Estate & Wang Jong / Sani \\
\hline 9 & Indah Industrial Park & PT Teluk Pantaian Indah \\
\hline 10. & Kabil Industrial Estate & $\begin{array}{l}\text { PT Citramas Indah Realtindo, PT Toba } \\
\text { Sejahtera }\end{array}$ \\
\hline 11. & Kara Industrial Park & Chandra Lukito \\
\hline 12. & Kawasan Bintang Industri II & Rijali \\
\hline 13. & $\begin{array}{l}\text { Kawasan Sekupang Makmur } \\
\text { Abadi }\end{array}$ & $\begin{array}{l}\text { PT Gunatama CP, Soetikno S., PT } \\
\text { Denis Melica IB }\end{array}$ \\
\hline 14. & Latrade Industrial Park & Latrade Pte Ltd $100 \%$ \\
\hline 15. & Megacipta Industrial Park & - \\
\hline 16. & Panbil Industrial Estate & PT Nusatama Properta Panbil \\
\hline 17. & Puri Industrial Park 2000 & PT Teluk Pantaian Indah \\
\hline 18. & Taiwan International Park & $\begin{array}{l}\text { PT Suar Batam International } \\
\text { Development Co. }\end{array}$ \\
\hline 19. & Tunas Industrial Estate & Doly \\
\hline 20. & Union Industrial Park & PT Union Batam Abadi \\
\hline 21. & Sarana Industrial Point & Sumarno \\
\hline
\end{tabular}


Tabel 2

Jumlah Perusahaan yang Terdaftar Pada Dinas Tenaga Kerja Kota Batam Periode Tahun 2014 s.d Desember 2015

\begin{tabular}{clc}
\hline No. & \multicolumn{1}{c}{ Bidang Usaha } & $\begin{array}{c}\text { Jumlah } \\
\text { Perusahaan }\end{array}$ \\
\hline 1. & Bangunan & 131 \\
2. & Industri & 960 \\
3. & Jasa & 581 \\
4. & Keuangan dan asuransi & 49 \\
5. & Listrik, gas dan air & 19 \\
6. & Perdagangan dan perhotelan & 515 \\
7. & Pertambangan & 2 \\
8. & Pertanian, kelautan dan perikanan & 11 \\
\hline \multicolumn{2}{l}{ Jumlah } & 2268 \\
\hline
\end{tabular}

Berdasarkan data dilapangan berkenaan dengan perlindungan norma kerja tidak terjadi pelanggaran yang signifikan. Hal ini karena gencarnya instansi terkait, yaitu Dinas Tenaga Kerja Kota Batam dalam mensosialisasikan berbagai peraturan yang berkaitan dengan norma kerja terutama pada perusahaanperusahaan skala besar. Angket yang disebarkan rata-rata pada pekerja di perusahaan besar, seperti PT Shimano Batam, PT Nov Fropab dan PT Epson Batam. Meskipun demikian, pada perusahaan skala kecil masih terdapat pelanggaran norma kerja, seperti tidak didaftarkannya pekerja kontrak pada BPJS Kesehatan dan BPJS Ketenagakerjaan. Alasan perusahaan tidak mendaftarkannya karena beranggapan tenaga kerja hanya dikontrak dalam waktu yang tidak lama dan apabila terjadi kecelakaan maka akan ditanggung langsung oleh perusahaan. ${ }^{15}$
Padahal, secara normatif setiap pemberi kerja wajib mendaftarkan tenaga kerjanya pada BPJS Ketenagakerjaan maupun BPJS Kesehatan sebagai bentuk jaminan atas kesehatan, keselamatan dan kesejahteraan tenaga kerja.

Secara umum, problematika yang sering muncul berkaitan dengan hubungan ketenagakerjaan di Kota Batam terkait masalah perjanjian kerja waktu tertentu (PKWT), upah dan Penyelesaian Hubungan Industrial (PHI) berkaitan dengan pemberian pesangon. Tetapi, khusus mengenai penyelesaian permasalahan $\mathrm{PHI}$ tersebut merupakan kompetensi peradilan, yaitu $\mathrm{PHI},{ }^{16}$ sedangkan yang menjadi fokus pembahasan terkait problem PKWT dan upah. Problem tersebut merupakan permasalahan klasik di Kota Batam yang harus diselesaikan oleh Dinas Tenaga Kerja Kota Batam.

${ }^{15}$ Wawancara dengan Rahmawita selaku mantan HRD pada salah satu perusahaan di Kota Batam pada tanggal 19 September 2016.

${ }^{16}$ Wawancara Tukiman, SE selaku Kasi Hubungan Industrial Orang Pekerja dan Pengusaha pada Dinas Tenaga Kerja Kota Batam pada tanggal 19 September 2016. 


\section{Problem PKWT}

Hubungan ketenagakerjaan dengan PKWT sebagai salah satu problematika hubungan ketenagakerjaan di Kota Batam memang sejatinya merupakan sebuah praktik bisnis biasa. Namun, di Indonesia dan banyak negara lainnya, praktik ini dapat membawa efekyang tidak baik, bersifat diskriminatif dan eksploitatif terhadap tenaga kerja di tengah semakin lemahnya kompetensi, peran dan fungsi pengawasan yang dilakukan oleh Dinas Tenaga Kerja.

Tenaga kerja pada umumnya yang bekerja pada perusahaan-perusahaan di Kota Batam bekerja berdasarkan kontrak PKWT. Menurut peneliti, problematika ini muncul karena lemahnya ketentuan di dalam Undang-Undang Nomor 13 Tahun 2003 tentang Ketenagakerjaan yang mengatur PKWT, sehingga menyebabkan perusahaan lalaidalam menaati.

Menurut Undang-Undang Nomor 13 Tahun 2003 tentang Ketenagakerjaan pada Pasal 56 Ayat (2) menentukan bahwa PKWT didasarkan pada jangka waktu atau selesainya suatu pekerjaan tertentu. Pada dasarnya, PKWT hanya bisa diterapkan dalam pekerjaan yang bersifat sementara atau musiman dan tidak berlanjut terus menerus. Namun, dengan adanya ketentuan bahwa PKWT dapat dilakukan atas dasar "jangka waktu" tanpa melihat sifat dari suatu pekerjaan, mengakibatkan pasal tersebut ditafsirkan bahwa PKWT dapat diterapkan secara alternatif, baik berdasarkan jangka waktu atau didasarkan pada selesainya pekerjaan tertentu. Menurut salah seorang informan yang pernah bekerja pada bagian HRD salah satu perusahaan subcon menyatakan bahwa "hal tersebut sering dijadikan alasan bagi perusahaan untuk menerapkan PKWT". "Kadangkala perusahaan beralasan mendapatkan permintaan pasar yang tidak dapat diselesaikan oleh perusahaan maincon pada jangka waktu yang diinginkan oleh pihak distributor, sehingga perusahaan menyerahkan sebagian pekerjaan pada perusahaan subcon yang pada dasarnya pekerjaan inti". Pekerjaan inti menurut ketentuannya harus dikerjakan oleh karyawan PKWTT". Keadaan lain bisa saja terjadi, perusahaan maincon meminta tenaga kerja dari subcon untuk dipekerjakan pada perusahaan maincon tersebut, dengan alasan pekerjaan tidak dapat dikerjakan pada subcon demi terjaminnya produk. Contoh pada perusahaan $X$ yang bergerak di bidang farmasi mempekerjakan karyawan dari perusahaan $\mathrm{Y}$ dengan sistem kontrak untuk mengerjakan pekerjaan inti dari perusahaan $\mathrm{X}$, dengan alasan untuk menjamin kualitas produk. ${ }^{17} \mathrm{Hal}$ ini juga pernah dialami oleh salah seorang karyawan yang bekerja di Kota Batam. ${ }^{18}$

Berdasarkan keterangan dari responden penelitian, pengusaha menyukai sistem PKWT untuk membatasi upah agar berkisar pada skala minimum dan menghindari pesangon apabila tenaga kerja dipekerjakan dengan sistem PKWTT. Sistem PKWTT dianggap sangat membebani perusahaan, sehingga dalam praktiknya banyak perusahaan merekrut tenaga kerja menggunakan sistem PKWT. ${ }^{19}$

\footnotetext{
${ }^{17}$ Wawancara dengan Rahmawita selaku mantan HRD pada salah satu perusahaan di Kota Batam pada tanggal 19 September 2016.

${ }^{18}$ Wawancara dengan Rita selaku tenaga kerja salah satu perusahaan farmasi di Kota Batam pada tanggal 21 September 2016.

${ }^{19}$ Wawancara dengan Meiv selaku tenaga kerja salah satu perusahaan manufaktur di Kota Batam pada tanggal 21 September 2016.
} 
Bila PKWT tidak sesuai ketentuan yang berlaku maka hakekat perlindungan hukum yang diberikan oleh undang-undang menjadi terabaikan. Padahal untuk mengantisipasi hal tersebut, pemerintah melalui instansi terkait sudah membuat kebijakan mengenai perlunya melakukan register atau pencatatan terhadap PKWT ke Dinas Tenaga Kerja setempat. Selanjutnya dapat diberikan penilaian terhadap PKWT itu layak diberlakukan atau tidak dalam jenis pekerjaan yang dicatatkan.

Selain itu, adanya kecenderungan bahwa di dalam PKWT menggunakan klausula baku yang melemahkan posisi tawar pekerja terhadap pengusaha. Dalam praktik, perjanjian kerja seringkali dibuat dalam model klausula baku. Adapun yang menjadi persoalan dalam penggunaan klausula baku tersebut, yakni tidak adanya posisi tawar yang seimbang antara pengusaha/pemberi kerja dengan tenaga kerja dalam penyusunan kontrak kerja. Bahkan, dalam beberapa kasus salinan kontrak kerja tidak diberikan kepada pekerja.

Menurut Undang-Undang Ketenagakerjaan pada Pasal 54 Ayat (2) menegaskan bahwa "perjanjian kerja termasuk didalamnya adalah perjanjian kerja waktu tertentu, khusus mengenai upah dan syarat-syarat kerja tidak boleh bertentangan dengan peraturan perusahaan, perjanjian kerja dan peraturan perundang-perundangan yang berlaku". Namun, dalam praktik isi PKWT banyak dibuat di bawah standar peraturan perundangundangan, peraturan perusahaan maupun perjanjian kerja bersama. Pengusaha cenderung mengakui hak-hak yang diterima oleh pekerja PKWT hanya sebatas yang ada dalam kontrak kerja, sementara hak-hak lain yang diatur dalam peraturan perundang-undangan dianggap tidak wajib diberikan oleh pengusaha.

\section{Problem upah}

Upah yang selama ini sebagai bagian dari proses tawar-menawar antara pekerja dan pengusaha, harus memperhatikan keseimbangan dan prinsip tandingan dengan memasuki wilayah-wilayah hukum progresif, seperti dalam konteks Arrest Hoge Raad 1919 dalam kasus Lindenbaum dan Cohen. Pembayaran upah pekerja tidak saja berdasarkan prinsip tawar-menawar "yang tidak seimbang antara pekerja dan pengusaha", tetapi memperhatikan kaedah-kaedah sosial di masyarakat, seperti kepatutan, kepantasan dan kewajaran dalam membayarkan upah dengan nilai-nilai kemahalan harga kebutuhan pokok pekerja. $^{20}$

Dalam menanggapi permasalahan upah, Pemerintah Kota Batam tetap berupaya untuk memperjuangkan standar upah yang memenuhi kelayakan bagi para pekerja. UMK Batam untuk Tahun 2016 berdasarkan Surat Keputusan Gubernur Kepulauan Riau Nomor 1737 Tahun 2015 tentang Upah Minimum Kota Batam Tahun 2016 ditetapkan sebesar Rp 2.994.111,00 (Dua Juta Sembilan Ratus Sembilan Puluh Empat Ribu Seratus Sebelas Rupiah) per bulan.

Selain menetapkan UMK, Pemerintah Kota Batam juga berupaya menetapkan Upah Minimum Sektoral (UMS) berdasarkan sektor pekerjaan guna melindungi pekerja yang mempunyai masa kerja kurang dari satu tahun. UMS Kota Batam 2016 mulai berlaku tanggal 2 Juni 2016 seiring diterbitkannya Kepulauan Gubernur Kepulauan Riau Nomor 1832 Tahun

\footnotetext{
${ }^{20}$ Zulkarnain Ibrahim, Hakekat Hukum Pengupahan Dalam Upaya Mewujudkan Kesejahteraan Sosial Pekerja, Jurnal Masalah-Masalah Hukum, Volume 44, Nomor 1, Tahun 2015, hlm. 442.
} 
2016. Penetapan UMS Kota Batam ini sesuai dengan Rekomendasi Walikota Batam Namor 77/TK/V/2016 tanggal 23 Mei 2016 tentang Rekomendasi Upah Minimum Sektoral Kota Batam Tahun 2016.

Sesuai ketentuan, UMS tidak boleh lebih rendah dari UMK Batam Tahun 2016 yang ditetapkan sebesar Rp 2.994.111. UMS diberlakukan hanya bagi pekerja yang mempunyai masa kerja kurang dari satu tahun, sedangkan untuk pekerja dengan masa kerja di atas satu tahun dilakukan kenaikan melalui perundingan bersama antara pengusaha dan pekerja/wakil pekerja dengan sebaikbaiknyasesuai struktur dan skala upah yang telah diberlakukan perusahaan. Bagi perusahaan yang telah memberikan upah lebih tinggi dari ketetapan UMK tidak dibenarkan mengurangi atau menurunkan upah. ${ }^{21}$

UMS Kota Batam dibagi menjadi 3 sektor jenis usaha yang merujuk kepada KBLI (Klasifikasi Baku Lapangan Usaha Indonesia) Tahun 2009 dengan besaran upah sektoral sebagai berikut.

1. Upah sektor I Rp 2.998.454 meliputi sektor industri tekstil, industri pakaian jadi, industri kulit, barang dari kulit dan alas kaki, industri kertas dan barang dari kertas, perdagangan besar, kecuali mobil dan sepeda motor, penyediaan akomodasi, penyediaan makanan dan minuman, jasa keuangan dan asuransi, real estate, jasa agen perjalanan, penyelenggara tur dan jasa reservasi lainnya, serta kegiatan olahraga dan rekreasi lainnya

2. Upah sektor II Rp 3.027.855, meliputi sektor industri bahan kimia dan barang dari bahan kimia, industri farmasi, produk obat dan jamu, industri karet, barang dari karet dan plastik, industri barang logam, kecuali mesin dan peralatannya, industri komputer, barang elektronik dan optik, industri peralatan listrik, industri mesin dan perlengkapan yang tidak dapat diklasifikasikan di tempat lain (YTDL), industri kendaraan bermotor, trailer dan semi trailer, industri pengolahan lainnya, serta pengadaan listrik, gas, uap/air panas dan udara dingin.

3. Upah sektor III Rp 3.203.699 meliputi sektor pertanian, peternakan, perburuan dan kegiatan (ang berhubungan dengan itu (YBDI), pertambangan minyak bumi dan gas alam dan panas bumi, industri makanan, industri bahan kimia dan barang dari bahan kimia, industri barang galian bukan logam, industri logam dasar, industri barang logam, kecuali mesin dan peralatannya, industri alat angkut lainnya, jasa reparasi dan pemasangan mesin dan peralatan, pengadaan air, konstruksi gedung, konstruksi bangunan sipil serta konstruksi khusus.

Berdasarkan hasil penelitian diperoleh keterangan bahwa rata-rata perusahaan besar di Kota Batam sudah membayarkan upah tenaga kerja sesuai dengan ketentuan yangberlaku. Hal ini terlihat dari 50 orang responden penelitian, yaitu tenaga kerja yang bekerja pada perusahaan besar, umumnya mengatakan bahwa upah yang dibayarkan

${ }^{21}$ Wawancara dengan Tukiman, SE selaku Kasi Hubungan Industrial Orang Pekerja dan Pengusaha pada Dinas Tenaga Kerja Kota Batam pada tanggal 20 September 2016. Hal ini juga dibenarkan RHW salah seorang mantan Staff HRD pada PT X di Batam, wawancara pada tanggal 21 September 2016. 
sebagai bentuk gaji pokok sudah mengikuti ketentuan UMK dan UMS Kota Batam.

Namun problematika upah yang sering muncul, yaitu lemahnya posisi tawar antara pekerja dengan pengusaha untuk menetapkan upah sesuai dengan standar kebutuhan hidup layak di Kota Batam. Dengan kata lain, kebijakan upah minimum belum berpengaruh secara signifikan terhadap peningkatan pendapatan buruh. Dengan ditetapkannya UMS Kota Batam tahun 2016 melalui Keputusan Gubernur Kepulauan Riau Nomor 1832 Tahun 2016 masih saja menuai kontroversi dikalangan buruh/ tenaga kerja yang menuntut UMS disesuaikan dengan standar perekonomian. Namun, tetap saja posisi tawar tenaga kerja lemah dibandingkan pengusaha, sedangkan Pemerintah sendiri tidak mau ambil risiko "larinya" investor.

\section{Faktor-faktor Penyebab Problematika Ketenagakerjaan di Kota Batam}

Dari berbagai problematika yang ada, dapat penulis deskripsikan beberapa faktor penyebab terjadinya problematika dalam hubungan ketenagakerjaan di Kota Batam sebagai berikut.

\section{Faktor yuridis, berupa kekeliruan penafsiran Undang-Undang}

Menurut Undang-Undang Nomor 13 Tahun 2003 tentang Ketenagakerjaan pada Pasal 56 Ayat (2) menentukan bahwa PKWT didasarkan pada jangka waktu atau selesainya suatu pekerjaan tertentu. Pada dasarnya PKWT hanya bisa diterapkan dalam pekerjaan yang bersifat sementara atau musiman dan tidak berlanjut terus menerus. Namun, dengan adanya ketentuan bahwa PKWT dapat dilakukan atas dasar "jangka waktu" tanpa melihat sifat dari suatu pekerjaan, mengakibatkan pemahaman dari pasal tersebut ditafsirkan bahwa PKWT dapat diterapkan secara alternatif, baik berdasarkan jangka waktu atau didasarkan pada selesainya pekerjaan tertentu. Tentu saja hal tersebut melanggar ketentuan undang-undang. Padahal PKWT hanya dapat diterapkan pada pekerjaanpekerjaan sebagaimana yang ditentukan Pasal 59 Ayat (1) Undang-Undang Nomor 13 Tahun 2003 tentang Ketenagakerjaan bahwa PKWT hanya dapat dibuat untuk pekerjaan tertentu yang menurut jenis dan sifat atau kegiatan pekerjaannya akan selesai dalam waktu tertentu, yaitu:

1. Pekerjaan yang sekali selesai atau yang sementara sifatnya.

2. Pekerjaan yang diperkirakan penyelesaiannya dalam waktu yang tidak terlalu lama dan paling lama 3 (tiga) tahun.

3. Pekerjaan yang bersifat musiman, atau

4. Pekerjaan yang berhubungan dengan produk baru, kegiatan baru, atau produk tambahan yang masih dalam percobaan atau penjajakan.

Selanjutnya menurut Undang-Undang Nomor 13 Tahun 2003 tentang Ketenagakerjaan pada Pasal 59 Ayat (2) menentukan bahwa PKWT tidak dapat diadakan untuk pekerjaan yang bersifat tetap. Pekerjaan tetap adalah pekerjaan yang sifatnya terus-menerus, tidak terputus-putus, tidakdibatasi waktu dan merupakan bagian dari suatu proses produksi dalam satu perusahaan. ${ }^{22}$

Selain itu, pelanggaran ketentuan PKWT tidak dikategorikan sebagai pelanggaran

${ }^{22}$ Romi, Kepastian Hukum Pengaturan Perjanjian Kerja Waktu Tertentu Dari Perspektif Peraturan Perundang-Undangan Ketenagakerjaan, Jurnal IImu Hukum Yustisia, Tahun 19, Volume 2, Juli-Desember 2012, hlm. 257. 
terhadap hak-hak normatif, melainkan dianggap sebagai sengketa privat/perdata yang berujung penyelesaian pada $\mathrm{PHI}$, sehingga tenaga kerja berada pada posisi yang lemah dalam sengketa tersebut. Padahal, dalam praktiknya pelaksanaan PKWT sering merugikan pihak tenaga kerja.

2. Kelemahan sistem register yang ditetapkan peraturan perundangundangan

Registrasi/pencatatan PKWT pada dasarnya merupakan sarana untuk menegakkan peraturan tentang PKWT. Pencatatan dapat menjadi sarana preventif untuk mencegah merebaknya PKWT dalam pekerjaan yang bersifat tetap (berkesinambungan). Berkenaan dengan hal tersebut, Dinas Tenaga Kerja Kota Batam melalui Bidang Hubungan Industrial dan Syarat-Syarat Kerja, sudah melakukan kebijakan berkenaan dengan koreksi dan registrasi PKWT.

\section{Tidak diaturnya sanksi terhadap pelanggaran PKWT}

Dalam Undang-Undang Nomor 13 Tahun 2003 tentang Ketenagakerjaan maupun dalam Kepmenakertrans Nomor KEP.100/MEN/VI/ 2004 tentang Ketentuan Pelaksanaan Perjanjian Kerja Waktu Tertentu, tidak mengatur ketentuan mengenai sanksi, baik sanksi administratif, pidana maupun perdata bagi perusahaan yang mempekerjakan buruh secara kontrak dalam pekerjaan yang bersifat tetap. Hal ini mengakibatkan bahwa Pegawai Pengawas Ketenagakerjaan tidak dapat menindak pengusaha apabila terjadi hal yang demikian. Pada akhirnya, pelanggaran terhadap ketentuan PKWT baru dianggap sebagai sebuah perselisihan ketika pekerja melaporkan karena merasa dirugikan. Intinya, kejadian pelanggaran PKWT diketahui bukan dari hasil temuan instansi terkait, tetapi berdasarkan dari hasil laporan/pengaduan tenaga kerja yang dirugikan.

Dalam situasi inilah PKWT dirasakan sangat tidak adil oleh tenaga kerja karena hakhak tenaga kerja tidak dilindungi secara maksimal. Seharusnya, tenaga kerja berhak atas perlindungan preventif, maksudnya setiap tenaga kerja sebelum kontrak dilaksanakan semestinya mendapa perlindungan dari instansi yang berwenang untuk memastikan bahwa kontrak yang ditandatangani tidak melanggar ketentuan yang berlaku.

\section{Faktor lemahnya sistem pengawasan ketenagakerjaan}

Dalam pelaksanaan penegakan hukum, faktor keberadaan penegak hukum berperan penting untuk terlaksananya hukum sesuai harapan. Ketentuan hukum mengenai sistem pengawasan ketenagakerjaan pada dasarnya telah mengakomodasi standar-standar kepatutan yang diperkuat oleh ketentuan perundangundangan di bidang ketenaga-kerjaan.

Salah satunya diatur dalam UndangUndang Nomor 13 Tahun 2003 tentang Ketenagakerjaan. Menurut Undang-Undang Nomor 13 Tahun 2003 tentang Ketenagakerjaan pada Pasal 176 menenukan bahwa "Pengawasan ketenagakerjaan dilakukan oleh pegawai pengawas ketenagakerjaan yang mempunyai kompetensi dan independen guna menjamin pelaksanaan peraturan perundang-undangan ketenagakerjaan.

Berdasarkan inventarisir data sekunder, pengaturan mengenai pengawasan di bidang ketenagakerjaan telah mengalami perkembangan yang signifikan dan telah diatur dalam sejumlah peraturan perundangundangan, meliputi: 
1. Undang-Undang Nomor 3 Tahun 1951 tentang Pernyataan Berlakunya Undang-Undang Pengawasan Perburuhan Tahun 1948.

2. Peraturan Menteri Nomor 3 Tahun 1984 tentang Pengawasan Ketenagakerjaan Terpadu.

3. Undang-Undang Nomor 13 Tahun 2003 tentang Ketenagakerjaan.

4. Undang-Undang Nomor 21 Tahun 2003 tentang Pengesahan Konvensi ILO No. 81 (1947) tentang Pengawasan Ketenagakerjaan dalam Industri dan Perdagangan (Labour Inspection in Industry and Commerce).

Dengan disahkannya Konvensi ILO tersebut maka diharapkan fungsi pengawasan dapat memenuhi standar hukum internasional, serta dapat memperkuat pengaturan pengawasan ketenagakerjaan sebagaimana yang diatur dalam Undang-Undang Nomor 13 Tahun 2003 tentang Ketenagakerjaan.

Namun, meskipun telah diakomodir dalam sejumlah peraturan, masih terdapat beberapa permasalahan pengawasan yang berakibat pada lemahnya sistem pengawasan ketenagakerjaan di Kota Batam. Kondisi lemahnya sistem pengawasan ketenagakerjaan di Kota Batam pada prinsipnya disebabkan ketidakjelasan kedudukan pegawai pengawas ketenagakerjaan. Pengawasan ketenagakerjaan selama ini tidak dipandang sebagai suatu sistem penegakan hukum, tetapi hanya sekedar pelaksanaan kewenangan aparat negara yang sifatnya terbatas. Selain itu, keberadaan sumber daya manusia yang terbatas dalam melakukan pegawasan ketenagakerjaan merupakan faktor lemahnya sistem pengawasan yang secara tidak langsung akan mempersulit penegakan hukum ketenagakerjaan. Untuk Pemerintah Kota Batam pada saat ini, Dinas Tenaga Kerja Kota Batam hanya memiliki sekitar 20 (dua puluh) orang tenaga pengawas ketenagakerjaan, dengan ratio 1:8. Artinya, 1 (satu) petugas pengawas untuk 8 (delapan perusahaan). ${ }^{23}$ Angka yang demikian, tentu tidak efektif untuk mengawasi sekitar 2.268 perusahaan yang terdapat di Kota Batam.

Mencuatnya permasalahan ketenagakerjaan di Kota Batam bukan karena adanya temuan dari tenaga pengawas yang bersangkutan, melainkan hanya berdasarkan laporan dari tenaga kerja yang merasa dirugikan. Jika hal tersebut berjalan terus menerus tanpa ada solusi dari pemerintah, maka permasalahan ketenagakerjaan akan sulit diminimalisir, terutama persoalan yang berkaitan dengan perlindungan terhadap pekerja PKWT maupun perlindungan terhadap upah.

\section{Kebijakan Pemerintah Daerah Mengatasi Problematika Ketenagakerjaan}

Menurut hasil penelitian bahwa tidak banyak hal yang dapat dilakukan oleh pemerintah Daerah Kota Batam dalam menangani permasalahan ketenagakerjaan. Hal-hal yang selama ini dapat dilakukan oleh instansi terkait, yaitu Dinas Tenaga Kerja Kota Batam hanyalah melakukan pengawasan-pengawasan yang berkaitan dengan perlindungan norma kerja. Apabila terjadi pelanggaran terhadap norma kerja dalam perjanjian kerja maka instansi terkait hanya memberikan teguran maupun peringatan kepada pihak perusahaan untuk tidak melanggar norma kerja.

\footnotetext{
${ }^{23}$ Wawancara Yusbah selaku Pegawai Sekretariat Dinas Ketenagakerjaan Kota Batam pada tanggal 20 September 2016.
} 
Munculnya kasus-kasus ketenagakerjaan di Kota Batam sampai saat ini hanya dipandang sebagai kasus yang muncul setelah adanya pengaduan/laporan dari pihak yang dirugikan, bukan karena adanya temuan. Hal ini membuktikan sistem pengawasan ketenagakerjaan tidak berjalan maksimal ditambah dengan kondisi sumber daya (personil) pengawasan yang tidak seimbang dengan jumlah perusahaan yang ada di Kota Batam. Sejauh ini, apabila ditemukan permasalahan yang berkaitan dengan tenaga kerja, pihak terkait, yaitu Dinas Tenaga Kerja Kota Batam melakukan upaya-upaya, seperti. ${ }^{24}$

1. Melakukan pencatatan PKWT dan koreksi terhadap PKWT yang belum memenuhi standar peraturan.

2. Melakukan koreksi atas peraturan perusahaan yang memerlukan pengesahan.

3. Melakukan proses mediasi terhadap permasalahan tenaga kerja dan memberikan saran-saran untuk perbaikan.

Namun, terhadap permasalahan yang menemui jalan buntu dalam proses mediasi akan dilanjutkan penyelesaiannya ke $\mathrm{PHI}$.

\section{Kesimpulan}

1. Secara tekstual, Undang-Undang Nomor 13 Tahun 2003 tentang Ketenagakerjaan telah cukup memberikan pengakuan dan jaminan hukum terhadap hak-hak buruh. Namun, penegakan hukumnya masih lemah sehingga belum mampu mewujudkan perlindungan hak-hak buruh. Hal inilah yang menyebabkan munculnya problematika ketenagakerjaan. Adapun problematika ketenagakerjaan yang sering muncul di Kota Batam berkaitan dengan PKWT yang dilanggar pihak perusahaan dan upah yang belum memenuhi standar perekonomian.

2. Faktor penyebab problematika ketenagakerjaan di Kota Batam, yaitu faktor yuridis berupa kekeliruan menafsirkan undangundang, kelemahan sistem register yang ditetapkan peraturan perundang-undangan, tidak diaturnya sistem sanksi terhadap pelanggaran PKWT, dan faktor lemahnya sistem pengawasan ketenagakerjaan.

3. Tidak banyak hal yang dapat dilakukan oleh Pemerintah Daerah Kota Batam dalam menangani permasalahan ketenagakerjaan. Apabila ditemukan permasalahan yang berkaitan dengan tenaga kerja, pihak terkait, yaitu Dinas Tenaga Kerja Kota Batam berusaha melakukan upayaupaya,seperti melakukan pencatatan PKWT dan koreksi terhadap PKWT yang belum memenuhi peraturan, melakukan koreksi atas peraturan perusahaan yang memerlukan pengesahan, melakukan proses mediasi terhadap permasalahan tenaga kerja, dan memberikan saran-saran untuk perbaikan.

\section{Referensi}

Adi Neka Fatyandri dan Evi Silvana Muchsinati. Pengaruh dan Peran Manajer SDM Terhadap Keharmonisan Hubungan Industrial di Kota Batam. Jurnal Manajemen. Volume 14. Nomor 1. November 2014.

Asep Ahmad Saetuloh. Kebijakan Ketenagakerjaan pada Sektor Industri di Kota Batam. JurnalKajian. Volume 16. Nomor 1. Maret 2011.

${ }^{24}$ Wawancara dengan Tukiman, SE selaku Kasi Hubungan Industrial Orang Pekerja dan Pengusaha pada Dinas Tenaga Kerja Kota Batam pada tanggal 20 September 2016. 
Asri Wijayanti. 2011. Menggugat Konsep Hubungan Kerja. Bandung: CV Lubuk Agung.

Dwi Afni Maileni. Tanggung Jawab Badan Nasional Penempatan dan Perlindungan Tenaga Kerja Indonesia Kota Batam Dalam Peningkatan Mutu dan Kualitas Calon Tenaga Kerja Indonesia Tinjauan Undang-Undang Nomor 39 Tahun 2004 tentang Penempatan dan Perlindungan Tenaga Kerja Indonesia di Luar Negeri. Jurnal Petita. Volume 2. Nomor 2. Desember 2015.

Fenny Natalia Khoe. Hak Pekerja yang Sudah Bekerja Namun Belum Menandatangani Perjanjian Kerja Atas Upah Ditinjau Atas Upah Berdasarkan Undang-Undang Nomor 13 Tahun 2003 tentang Ketenagakerjaan. Jurnal IImiah Mahasiswa Universitas Surabaya. Volume 2. Nomor 1. 2013.

I Nyoman Wahyu Triana dan I Made Udiana.

Kesepakatan Pemutusan Hubungan Kerja (PHK) Melalui Perjanjian Bersama Ditinjau Dari Aspek Hukum Ketenagakerjaan. Jurnal Kertha Semaya. Volume 04. Nomor 04. Juli 2016.

Irene Svinarky. Analisis Kinerja Karyawan Dari

Dampak Perjanjian Kerja Waktu Tertentu (PKWT) Terhadap Kepuasan Perusahaan di PT Osi Electronics di Kota Batam Periode Tahun 2013. Jurnal
Cahaya Keadilan. Volume 3. Nomor 1. 2015.

R. Joni Bambang S. 2013. Hukum Ketenagakerjaan. Bandung: Pustaka Setia.

Shinta Wahyu Hati, Rusda Irawati dan Aditia Wiranggga, Motivasi Kerja Terhadap Kondisi Sosial Ekonomi Tenaga Kerja Wanita di Sektor Industri. Proceeding Applied Business and Engineering Conference (ABEC) 2014.

Shinta Wahyu Hati. Analisis Keselamatan dan Kesehatan Kerja (K3) pada Pembelajaran di Laboratorium Program Studi Teknik Mesin Politeknik Negeri Batam. Prosiding SNE Pembangunan Manusia Melalui Pendidikan Dalam Menghadapi ASEAN Economic Community 2015.

Suratman dan Philips Dillah. 2014. Metode Penelitian Hukum, Cet. Ke-2. Bandung: Alfabeta.

Zulkarnain Ibrahim. Hakekat Hukum Pengupahan Dalam Upaya Mewujudkan Kesejahteraan Sosial Pekerja. Jurnal Masalah-Masalah Hukum. Volume 44. Nomor 1. Tahun 2015.

Romi. Kepastian Hukum Pengaturan Perjanjian Kerja Waktu Tertentu Dari Perspektif Peraturan Perundang-Undangan Ketenagakerjaan. Jurnal IImu Hukum Yustisia. Tahun 19. Volume 2. JuliDesember 201. 